\title{
実践研究
}

\section{相互信頼関係の形成と探索活動の促進を目指した教育的係わり合い 常同行動を示しコミュニケーション活動の初期状態にあった一女児の事例}

\author{
芳 野 正 昭*・菅 井 裕 行**・吉 武 清 実***
}

教育実践を、係わり手と子ども相互の見方と行動の革りをたすけあう過程として捉えてい く、という立場から、常同行動を示し、コミュニケーション活動の初期状態にあった、運動 障害を合せ持つ一女児 $(\mathrm{M})$ との約 10 年にわたる係わり合いの経過を取り上げ、そこから得 た知見を報告した。当初、M の行動観察から探索活動が極めて不活発な状態にあることに着 目し、探索活動の促進を目的とした係わり合いを開始したが、間もなく働きかけに対する明 確な拒否が生起するようになった。そこで方針を再検討し、係わり合いにおける問題は相互 信頼関係の形成であると捉え直して実行したところ、関係が進展するにつれ常同行動が減少 し、逆に探索活動が活発化していった。この経過から、常同行動、挆索活動、相互信頼関係 の三者関係について検討を加えた。さらに相互信頼関係における「柔らかな接触と声掛け」 による呼応の役割、カウンセリング的視点の必要性について整理した。

キー・ワード：相互信頼関係 探索活動 常同行動 コミュニケーション

\section{I .はじめに}

長期間にわたって、同じ行動を繰り返しており(「常 同行動」)、探索活動（梅津・譚, 19796) 態にある子供たちがいる。これらの子供たちの中には、 交信活動が初期状態にあって、生活の中で「安心」し

「落ち着いて」過ごすことができていないと実感され る子供たちが存在する。彼等に対しては、直ちに新奇 な「学習・課題場面」を提供するのではなく、時間を かけて相互に安心できる関係づくり（相互信頼関係の 形成）を行うことが、結果として探索活動の活発化を 促進させることへとつながるのではないか。

筆者等 (以下 $\mathrm{A}$ と略記) は、常同行動を頻繁に示し、 探索活動をほとんど示さなかった一女児 $(\mathrm{M})$ と教育 的係わり合いを持ち続けて約 10 年になる。Mにおい ては、特定の大人との間に相互信頼関係が形成される にともなって、常同行動が減少し、逆に探索活動が活 発化してきた。

本研究では、主に M の 10 歳時（1987 年 4 月）以降

*東北大学大学院

**宮城県立盲学校

***東北大学教育学部
の教育的係わり合いについて報告し、常同行動、探索 活動、相互信頼関係の三者関係について検討を加える。

\section{II . 事例の紹介}

\section{1. 事例の概要}

M（1977 年 2 月生まれの女児，係わり合い開始当時 4 歳 10 か月）との係わり合いを事例とする。週 1 回、 約 2 時間の係わり合いである。

\section{Mについての医学的診断等}

先天性内反足および先天性両側顔面神経麻痺（眼球 運動を含む)。1994 年現在、養護学校（高 2）に在籍。

\section{M の 10 歳時の生活の様子について}

（姿勢）あぐら座位、長座位、側臥位、仰臥位をと れる。空間移動は寝返りによるがまれ。(食事)手㨡み もしくはスプーンで食べる。コップの飲料水を一気に 飲もうとしてむせることが多い。䜩下がうまくできず、 口からあふれることが多い。(コミュニケーション)音 声による発信は観察されていない。その受信は数種 $(\mathrm{M}$ の名前，食べ物の名前)で、それら以外については受信 しているかどうかははっきりしない。顔面神経麻痺の ため、M の表情の変化はほとんど見られず、表情から $\mathrm{M}$ の情動を読み取ることは難しい。ぐずることや、モ 
ノのある方向への手伸ばしによって何かを訴える。

\section{10 歳時の係わり合いの時間帯の過ごし方}

10 歳当初の約 2 時間の係わり合いの間、Mにおいて は次の 5 つの行動を起こすことが優勢であった。それ は「ぐずる」「泣く」「手首捻りを繰り返し、持ってい る玩具（でんでん太鼓の類）を鳴らす」「飲食する」「眠 る」である。「ぐずる」「泣く」ことは日常頻繁に生じ た。これは新奇な人や、大勢の人のいる場に置かれた 場合に増加した。日中覚醒している時間帯の多くは、 手首捻りの反復による特定の玩具の音鳴らしを繰り返 すといった常同行動が続き、それ以外のモノへ自主的 に働きかける様子はほとんど見られなかった。以上の ような活動が幼児期から長期間続いていた。

上記のように、「ぐずり」や「泣き」などの粗大な調 整 (梅津, $1976^{5)}$ ) が目立ち、探索活動の生起が極めて 不活発な状態にあった。

\section{4 歳時から 10 歳時までの係わり合いの経過}

10 歳時以降の経過を述べる前に、Mの 4 歳時から 10 歳時までの経過の概要を述べ、問題を整理する。

\section{1 . 問 題}

1）泣き・ぐずりの頻発

$\mathrm{M}$ には日中覚醒している時間、頻繁にぐずり、泣く ことが見られた。母親を始め筆者等には、その原因を 特定できないことがしばしばであった。この頃、母親 は「 $\mathrm{M}$ がどうして泣くのか分からない」と漏らしてい る。回りの大人（母親を含む）は、ぐずり、这いてい る $\mathrm{M}$ を抱き上げたり、玩具や飲食物を $\mathrm{M}$ に提示する 方法で $\mathrm{M}$ を落ち着かせようとしてきたが、首尾よくい かないことが普通であった。

2 ）常同行動の頻発とその慢性化および探索活動 の長期間にわたる停滞

ぐずりや泣きの見られない時間帯の多くを、玩具を 持って手首捻りをしては音を鳴らすことを繰り返して 過ごしていた。玩具操作について、特に新しい展開は 見られず、数種類の特定の玩具以外はほとんど手にす ることもなく、同じ行動の繰り返しが続いていたし、 新しい活動に踏み出す様子も見られないという状態 が、長期にわたって続いていた。当時、母親は「M は 何年も同じことばかりしている。他のモノやことへ目 が向くようになって欲しい。」と訴えていた。

\section{2 . 対 処}

そこで、われわれは M における問題を、探索活動の 活発化を捉すことと捉え、次のように対処を考えた。 (探索について) モノへの接近、操作を中心にして、
新しさを含む状況への踏み出しを促す。その際、M の 視線や身体の動きから $\mathrm{M}$ の意向をていねいに読み取 りながら行う。(常同行動について)積極的には対処せ ず、それが一区切りして別の行動が発現するのを待つ。

\section{3. 実 行}

これらの対処を実行するうちに、そのように働きか けるAに対して、背を向けたり、腕で目を覆ってうな り声を上げたり等することが、明確になってきた。こ のような、働きかける A に対する回避の傾向がはっき りとする経過の中で、泣きやぐずりが、働きかける A に対する回避や拒みのそれであると、われわれに読み 取れるようになってきたし、M 自身、泣きやぐずりで はっきりと表出するようになってきた。

常同行動は以前と同様、顕著に観察され続けた。結 果として、新奇なモノへの接近と操作の活動は、不活 発のままであった。

\section{4. 問題の捉元直し}

$\mathrm{M}$ は頻繁に泣き、ぐずることを繰り返していたが、 母親との間にも、母親に「あやし甲斐」や「なだめ甲 斐」を実感させる形での、あやしあやされる関係やな だめなだめられる関係は未だ成り立っていなかった。 10 歳時までは、顔面神経麻痺のため表情の変化が見ら れない等、 $\mathrm{M}$ の発信が微弱であった。その為もあって $\mathrm{M}$ のぐずりや泣きの原因を特定することが困難で あったことや、Mにおける探索活動の活発化を促すこ とを、働きかけの中心としていたことから、われわれ は $\mathrm{M}$ が強い緊張状態にあることを重視できないでき た。次第に、A 等の働きかけに対する $\mathrm{M}$ の拒否や回避 が確明になってきた。そこで、われわれは $\mathrm{M} に$ に対して 新しい活動への踏み出しを促す前に、まず $\mathrm{M}$ が $\mathrm{A}$ 等 と一緒にいて安心できることが必要である、と考える ようになった。それは、“人の個体発生において特定の 大人との間で基本的信頼 (Erikson, 1981') $)$ と呼ばれる べきものが育っていかないならば、その人の生活は、 ゆとりやくつろぎの見られない不安等の緊張の持続状 態に置かれ易い。その時のその人の生活の主題は緊張 状態の解消、即ち信頼関係の形成であって、探索活動 は主題と成りがたい”と考えたからであった。

つまり、探索活動の活発化が、このときの $\mathrm{M}$ にと ての主たる課題なのではなく、特定の大人といて安心 できること、落ち着いてすごせること、即ち特定の人 との間で相互信頼関係の形成されることこそが、Mの 課題ではないかと考えたのだった。そして $\mathrm{M}$ が特定の 人を頼みとしていくこと（相互信頼関係の形成）は、 Mの泣きやぐずりの「呼」に「柔らかな接触（梅津， 
19684)）と声がけ」によって応えていく係わりから始ま ると考えた。

\section{5. 対処の変更}

（探索について）新しい活動への踏み出しを促すこ とを控え、無理をさせない。

（緊張状態について）「柔らかな接触と声がけ」によ る呼応を中心に、あやすことやなだめることを積極的 にしていく。これによって、M の苦痛や困惑の解消を たすけていく。

（常同行動について）常同行動については、これを 否定的に見ず、その活動が滞る度に滞りの解消を積極 的にたすける。

\section{10 歳以降の経過}

\section{1. 第 1 期 10 歳 3 ケ月〜 12 歳時の様子 (1987 年 5 月〜 1989 年 2 月)}

1）泣き・ぐずり・常同行動

M は、手足に触れられることを拒んでいたが、ぐず り、这いている時、背中であれば、ぐずりに合わせて $\mathrm{A}$ が触れることを許した。 $\mathrm{A}$ は $\mathrm{M}$ の背中をリズミカ ルに吒きながら「大丈夫」と静かに語りかけた。 $\mathrm{A}$ が あやすと、徐々にぐずりを納めることができるように なってきた (10 歳 4 ケ月〜)。また $\mathrm{M}$ は首を“カクン” と前に落し「ガッガッ」と言いながらぐずるのが常で あったが、この瞬間に背中を吒いてあやすと M はぐず る行動へ切り換えないでも済ませられるようになっ た。

同じ時期、 $\mathrm{M}$ はぐずる度に傍にいる $\mathrm{A}$ の髪を強く 引っ張るようになった。このことを、 $\mathrm{M} に$ に生じた動摇 をAに向けて攻撃することで納めようとしている姿 ではないか、とわれわれは考えた。 $\mathrm{M}$ はこのようなや り方でAを頼るようになってきたのではないか。

その後次第に $\mathrm{M}$ はぐずる、泣く行動をあまり起こさ ないで過ごすように変化してきた。

常同行動については、M が手を滑らせて玩具を落と した時には $\mathrm{A}$ はそれを拾って渡し、あるいは $\mathrm{A}$ も玩 具を手にして M の動作を M のすぐ横で真似るなどし て、M のこの活動が円滑に展開するようにたすけた。 次第に $\mathrm{M}$ は、 $\mathrm{A}$ の動作にも視線を向け、A と共同でこ の活動を為すようになった。さらには、一層この共同 での活動に集中して取り組むようになった。やがて、 長期間続いてきたこの常同行動に「飽和」の兆候が見 え始め、その後次第に生起する回数は減少していった。

2 ) 対人関係

まれに、M から手を伸ばしてきて $\mathrm{A}$ の顔（特に靧）
に少し触れては手を戻すことをし始めた（10 歳 3 ケ月 〜 8 ケ時)。そしてAにもたれかかるように A 上 腕に顔をつけ臭いをかぐ行動を毎回のように行いだし た (10 歳 8 ケ月時)。 $\mathrm{M}$ がコップや玩具を直接 $\mathrm{A}$ に差 し出して要求を出すことが、係わり時に毎回必ず見ら れるようになった(10 歳 8 ケ月時)。手の届かない所に あるモノを取って貪いたくて、M が手を伸ばした時、 それを A が読み取れないでいると、それまでであね代 忽ちぐずり始めたり、要求を諦めたりしていたのが、 この時期に至ってから、暫くしてから $\mathrm{M}$ はもう一度手 を伸ばしてくるようになった(11藏 1 ケ月)。Aの手を 掴んでの発信は 11 歳 1 ケ月に初めて見られたが、その 後は見られず、次に発現したのは $\mathrm{M}$ が母親や $\mathrm{A}$ の顔 を見る（13 歳 3 ケ月）ようになってからのことで、そ れ以降頻繁に発現するようになってきている。このよ うな発信行動の多様化に伴って、泣きやぐずりの発信 は減少していった。

母親も $\mathrm{M}$ の行動の読み取りを活発に行いだした。就 寝時、布団上を母親の傍まで寝返りで移動接近し、母 親の身体に触れた状態で眠ることが増えた。このよう に母親に甘える行動が増大し、「あやし、あやされる」 関係が成立してきた。母親から $\mathrm{A}$ への報告にも変化が 現われ、Mの泣きやぐずりに関して「何を言いたいの か分からない」という言葉が聞かれなくなった。

\section{2 . 第 2 期 12 歳時〜13 歳時の様子（1989 年 3 月} １993 年 2 月)

第 1 期の変化を考えて、引き続き「相互信頼関係」 の形成を図りながら、徐々に、探索活動への誘いの機 会を増やしていくことにした。

1) 常同行動・探索活動

M はキーボードやラジカセに手を伸ばすことをし 始めた。これらの機器を操作したり聴いたりと、活動 種に拡がりが見られだした。そして $\mathrm{M}$ は、Mの手を 取ってガイドするAの誘いを、それ程強く拒まなく なっていった（13歳 1 ケ月）。

A の発信を受けながら、新奇な場でもぐるりと回り のモノを見回すようになってきた(13 歳 3 ケ月)。この ように A を頼みとし、A と共同して新奇な場やモノへ 接近することが次第に増加してきた。

A を頼みとする行動が明確になるに伴って、手首捻 りの繰り返しによる玩具の音鳴らしが生起する頻度は 低下し、13 歳 4 ケ月以降殆ど見られなくなった。

\section{2 ）対人関係}

13 歳 4 ケ月を過ぎて、 $\mathrm{M}$ が母親の顔をじっと見ると いうことが初めて起こった。続いて A の顔をもじっと 
見るようになった。「見ること」が相互のコミュニケー ションに組み込まれてきた。その後1ケ月程してから、 $\mathrm{M}$ はまず母親と A に対して、相手の顔を見る事自体 が目的であるかのような見方をするようになった（13 歳 5 ケ月〜 7 ケ月)。1 回に凝視する時間は、長い時で 10 分から 20 分に及んだ。1 13 歳 8 ケ月になる、母親 とAに対してはこのように凝視し続けることはしな くなり、我々が呼びかけた時に視線を合わせることが、 見られるようになった。

その後、例えば M の要求していると思われるモノを 提示したところ M は先ずそのモノを見て、次に「これ でいい」と言うかのようにAの顔を見る、といった見 方もするようになった。

$\mathrm{M}$ が母親の顔をじっと見るようになり始めた頃か ら、母親も M に対して積極的に語り掛けるようになっ た。 $\mathrm{M} も 母$ 親の語り掛けをじっと聞くようになった。

初対面の人へ接近するということが生じてきた。例 えば、学校でのこと。少し離れた所にいる人を $\mathrm{M}$ は繰 り返し見た。その人が M の側にくると、M はその人の 腕を取って顔をつけた（13 歳1ケ月）。

13 歳 2 ケ月、母親は M のことを「分かる子なんだ」 と言い始めている。

\section{V. まとめと考察}

$\mathrm{M}$ の 10 歳時までの係わり合いにおいては、モノへ の接近・操作を促すことが、Aの働きかけの中心で あった。その後、働きかけに対するぐずりや泣きによ る拒みが明確になった。このことから、モノへの接近・ 操作を促す働きかけは、Mに無理を強いるものである と考えるようになった。この時点で、問題を再考し、 M の課題を相互信頼関係の形成であると考えて、対処 の変更を行った。その後の経過は次のような過程とし て整理できると考える。(1) M の苦痛や困惑の解消を たすけていく対処によって、M は A と一緒にいて安 心できるようになった。（2）この対処を通じて特定の 大人（母親，A）を頼みとする関係（相互信頼関係）の 形成が成立してきた。（3）特定の大人を頼みとして、 $\mathrm{M}$ は新しい活動へと踏み出していくようになった。そ の経過の中で長期間にわたって続いてきた常同行動は 減少した。

以下に $\mathrm{M}$ との係わり合いから筆者等が学んだこと について述べる。

1) 経過は、相互信頼関係が進展するにつれて、 常同行動が減少し、探索活動が活発化していったこと を示している。一般に、コミュニケーション活動が初
期状態にありかつ発信が微弱である場合には、回避や 拒みの表出が充分に大人に受け取られないことが多 い。そこでは、大人側からの指令的な発信が優勢であ る指導がなされがちで、この指導が思いがけず子供に 無理を強いるものになっていることがしばしばある。 このような状況の中にある子供達の中には、常同行動 や自傷行動、攻撃行動等を頻繁に示す者もいる。その ような場合、特定の大人を頼みとする関係（相互信頼 関係）を育むことこそが、まず重視されるべきことで あると考える。

2 ）常同行動については、その人にとってその行 動が生活全般の調整上の観点からみて、どのような機 能を果たしているかについての十分な検討が必要とさ れるのではないか。Mの場合、コミュニケーション活 動が初期状態にあって、かつ探索活動の生起が極めて 不活発な状態にあったことから、生活の中で出会う 種々の動摇を他者とのやりとりを通じて、あるいは適 宜行動を切り換えていくことで自己の調整を激しく乱 すことなく納めていくことが困難であったと思われ る。そのような状況下で M は常同行動を繰り返すこと で、かろうじて自己調整していたと思われる。

3) M 10 歳時以降、筆者等は常同行動を含む Mの起こす行動を否定的に見ないように努めてきた ように思われる。このことが、母親や A との間で「一 緒にいて安心できる関係」が育つ上で重要な条件の一 つとなったと考える。相手の行動を否定的に捉えず、 相互に安心できる関係を築くことがカウンセリングで 重視されている (Rogers, 19863) $)$ が、このカウンセリ ング的視点の重要性が本事例において示唆された。

4) 経過は、コミュニケーション活動の初期状態 にある人との相互信頼関係の形成にとって、泣きやぐ ずりや発声などの「呼」に対して柔らかな接触と声掛 けによって「応答する」働きかけの必要性を示した。 A らがこの点に着目した時点で $\mathrm{M}$ は既に 10 歳を過 ぎていた。年齢相応の振るまいを考えれば柔らかな接 触や声掛けといったやりとりには、意図的な努力が必 要であった。しかし、幼児期を過ぎた人であってもこ のやりとりから始めるべき場合があると考える。

5) M 913 歳時に、M が大人の「顔をじっと見 る」行動がコミュニケーションに組み込まれた。この ことは、循環せず途切れがちであったコミュニケー ション状態を循環させていく上で極めて重要な働きを したと考える。乳幼児研究において、母親と子どもの 目と目が合うことが母親の養育反応を刺激する解発因 (releaser) であるという指摘がある（Robson, 
$\left.1968^{2)}\right)$ 。M の母親においても、この行動の出現後、M に対する声掛けや会話の質と量が高まった。

\section{付 記}

本研究の一部は、日本特殊教育学会第 31 回大会にお いてロ頭発表された。

\section{文 献}

1) Erikson, E. H. (1959) Psychological Issues Vol I. No. 1. Monograph 1, International Universities Press Inc., New York. 小此木啓吾訳編 (1973) 自我同一性. 誠信書房.

2) Robson, K. S. (1968) The role of eye-to-eye contact in maternal infant attachment. Journal of
Child Psychology and Psychiatry, 8, 13-25.

3) Rogers, C. R. (1986) Client-Centered Therapy. Irwin L. Kutash. (Eds.), Theory and Technique in the Practice of Modern Therapies. Jossey-Bass Inc. California. 197-208.

4) 梅津八三 (1968) 野性览の問題. 三和書房.

5) 梅津八三 (1976) 心理学的行動図. 重複障害教育 研究所研究紀要創刊号, 1-44.

6) 梅津八三・譚 恵江 (1979) YA, NA, YK, KT, TZについての教育実践要録. 重複障害教育研 究会第 7 回全国大会通所指導に関する論集, 2 , 7-46.

- 1994.4.1. 受稿, 1994.12.3. 受理一 